\title{
Do Payroll Taxes in the United States Create Bunching at Kink Points?
}

\author{
David Powell
}




\title{
Do Payroll Taxes in the United States Create Bunching at Kink Points?
}

\author{
David Powell \\ RAND \\ September 2015 \\ Michigan Retirement Research Center
University of Michigan
P.O. Box 1248
Ann Arbor, MI 48104
www.mrrc.isr.umich.edu \\ (734) 615-0422
}

\section{Acknowledgements}

The research reported herein was performed pursuant to a grant from the U.S. Social Security Administration (SSA) funded as part of the Retirement Research Consortium through the University of Michigan Retirement Research Center (5 RRC08098401-07). The opinions and conclusions expressed are solely those of the author(s) and do not represent the opinions or policy of SSA or any agency of the Federal Government. Neither the United States Government nor any agency thereof, nor any of their employees, makes any warranty, express or implied, or assumes any legal liability or responsibility for the accuracy, completeness, or usefulness of the contents of this report. Reference herein to any specific commercial product, process or service by trade name, trademark, manufacturer, or otherwise does not necessarily constitute or imply endorsement, recommendation or favoring by the United States Government or any agency thereof.

\section{Regents of the University of Michigan}

Michael J. Behm, Grand Blanc; Mark J. Bernstein, Ann Arbor; Laurence B. Deitch, Bloomfield Hills; Shauna Ryder Diggs, Grosse Pointe; Denise Ilitch, Bingham Farms; Andrea Fischer Newman, Ann Arbor; Andrew C. Richner, Grosse Pointe Park; Katherine E. White, Ann Arbor; Mark S. Schlissel, ex officio 


\title{
Do Payroll Taxes in the United States Create Bunching at Kink Points?
}

\begin{abstract}
Much of the literature on labor supply responsiveness to taxes studies the effects of payroll and income taxes together, usually using income tax changes to identify effects. There is less research on how individuals respond to payroll taxes specifically. Given the salience of the payroll tax relative to other income taxes, it is possible that taxpayers respond differentially than income tax elasticities may suggest. Using data from the Social Security Administration, I exploit two recent short-term changes in payroll taxes to study whether labor earnings responded. The Making Work Pay Tax Credit reduced the payroll tax by 6.2 percentage points up to $\$ 6,451$ (\$12,903 for couples) of earnings in 2009 and 2010. I test for bunching at this kink. In 2011, payroll taxes were reduced by two percentage points, changing the incentives to bunch at the taxable earnings maximum. While many papers on bunching must make assumptions on the distribution of earnings in the absence of taxes, an advantage of studying changes in payroll taxes is that it is possible to observe the distribution in different years under different tax regimes. I find evidence of bunching induced by the payroll tax changes. I estimate a tax elasticity of labor earnings of 0.08 at the taxable earnings maximum, which suggests that policy proposals to raise or eliminate the payroll tax cap should consider labor supply behavioral responses to this policy. I also estimate larger responsiveness to the Making Work Pay Tax Credit.
\end{abstract}

\section{Citation}

Powell, David. 2015. "Do Payroll Taxes in the United States Create Bunching at Kink Points?” Ann Arbor, MI. University of Michigan Retirement Research Center (MRRC) Working Paper, WP 2015-327. http://www.mrrc.isr.umich.edu/publications/papers/pdf/wp327.pdf

\section{Authors' Acknowledgements}

I would like to thank conference and seminar participants at the Michigan Retirement Research Center Conference and the Social Security Administration for helpful comments. I appreciate the SSA's help with data access to the Continuous Work History Sample. Special thanks to Francoise Becker and Lynn Fisher. The research reported herein was performed pursuant to a grant from the U.S. Social Security Administration (Grant \#RRC08098401-07)). 


\section{Introduction}

Payroll taxes in the United States are a major source of government revenue and the primary mechanism of tax payments on labor earnings for the majority of households. Payroll taxes comprise over half of taxes on labor earnings in the United States (OECD (2015)). Over $65 \%$ of households pay more in payroll taxes than income taxes in a year (Joint Committee on Taxation (2015)). The ratio between payroll tax payments and income tax payments is especially large for low-income households and tends to decrease throughout the earnings distribution. Many recent tax reforms have operated through payroll taxes. In 2009 and 2010, the Making Work Pay Tax Credit was distributed primarily through new IRS withholding tables. In 2011 and 2012, a payroll tax holiday reduced the employee portion of payroll taxes by 2 percentage points. As part of the Patient Protection and Affordable Care Act (PPACA), the Medicare tax on labor earnings was increased by 0.9 percentage points for earnings above $\$ 200,000$ (\$250,000 for married couples).

In recent years, many policymakers have suggested altering the payroll tax schedule further, by raising or eliminating the Social Security taxable earnings maximum, which caps the payments that any individual can make in a year for Social Security taxes. Despite the cap on Social Security taxes, $83.1 \%$ of earnings were subject to Social Security taxes in 2013 (Social Security Board of Trustees (2015)). In 2012, Senator Mark Begrich and Congressman Ted Deutch introduced legislation to eliminate the payroll tax cap. Senator Bernie Sanders and Congressman Peter DeFazio proposed requiring Social Security taxes for earnings above $\$ 250,000$. There is precedent for such policy changes as the Medicare tax cap was eliminated in 1994. Consequently, payroll tax reform represents a possible mechanism to promote the future solvency of Social Security and Medicare. According to estimates by the Social Security Office of the Chief Actuary, eliminating the earnings cap on payroll 
taxes in 2016 would delay the depletion of the OASI and DI Trust Funds by 24 years to 2057. ${ }^{1}$ However, we have relatively little evidence about behavioral response to eliminating the cap.

A rich and influential literature estimates the elasticity of taxable income (e.g., Auten and Carroll (1999); Gruber and Saez (2002); Saez, Slemrod and Giertz (2012)). These papers use legislative tax schedule changes for identification. During the time periods used in this literature, these tax changes tend to be primarily related to income taxes, not payroll taxes. Furthermore, the literature models taxable income responsiveness as a function of taxes, aggregating together payroll and income taxes. There are reasons that people may respond to payroll taxes differently than income taxes. First, labor earnings may be more or less sensitive to taxes than other sources of income. Second, payroll taxes are more salient than income taxes, and this salience may influence the degree of household responsiveness. Understanding the importance of payroll taxes independent of income taxes is especially policy-relevant given that the degree to which taxes are collected through income taxes versus payroll taxes is a possible policy lever.

A smaller literature focuses on the consequences of payroll taxes. Saez, Matsaganis and Tsakloglou (2012) studies a payroll tax change in Greece in 1993. Lehmann, Marical and Rioux (2013) compares payroll tax responsiveness to income tax responsiveness in 2003-2006 France. Kugler and Kugler (2009) studies the incidence of a payroll tax increase in Colombia while Gruber (1997) examines similar outcomes in Chile.

Liebman and Saez (2006) uses behavioral responses to income tax changes to predict sensitivity to payroll tax changes in the United States. This paper also studies the earnings distribution around the taxable earnings maximum and finds little evidence of systematic avoidance of the kink. This result contrasts with my findings below as I estimate that when

\footnotetext{
${ }^{1}$ http://www.ssa.gov/OACT/solvency/PDeFazio_20150423.pdf
} 
the Social Security tax rate changed that the distribution of earnings around the taxable maximum changed. The differences in these conclusions provides support for the benefit of using policy changes to study behavioral responses in this context rather than studying cross-sectional variation in the earnings density.

This paper is the first to study labor supply responsiveness to payroll taxes in the United States. I estimate "bunching" near kinks generated by recent payroll tax credits. I also study the consequences of the payroll tax rate reduction on changes in the earning density at the kink generated by the taxable earnings maximum since the tax cut altered the incentives to locate near the kink in the budget constraint. Methodologically, the contribution of this paper is to use policy changes to study behavior around kink points. The bunching literature must assume that the distribution of earnings is constant within a small window around kinks or changes smoothly in a manner that can be modeled parametrically. In this paper, I permit arbitrary density changes throughout the earnings distribution and test whether there are discrete changes corresponding to policy reforms.

This strategy builds on a rich literature which develops econometric methods in the presence of nonlinear budget sets (Burtless and Hausman (1978); Hausman (1981, 1985)), including strategies which test predictions of bunching at convex kink points. Studying bunching has been used in an array of other applications such as responsiveness to a large kink in the Swedish tax schedule (Bastani and Selin (2014)), sensitivity to kinks in the Denmark tax schedule (Chetty et al. (2011)), and the relationship between kinks generated by pension reforms and retirement decisions (Brown (2013)). The literature on the Social Security Earnings Test documents substantial bunching due to the kink induced by the nonlinear nature of the policy (Friedberg (2000); Haider and Loughran (2008); Gelber, Jones and Sacks (2013)). The empirical strategy used in this paper builds primarily on the analysis in Saez (2010). Saez (2010) studies bunching around the kinks created by the Earned Income Tax 
Credit (EITC), finding strong evidence of bunching at the minimum income level necessary for receipt of the full tax credit. This bunching is driven by individuals with self-employment income, suggesting that at least part of this effect may be due to changes in reporting behavior, not actual labor supply behavior.

\section{Background}

\subsection{Payroll Taxes in the United States}

In the United States, Federal Insurance Contributions Act (FICA) taxes fund Social Security and Medicare. Since 1990, FICA taxes have included a 6.2\% Social Security tax on earnings up to the taxable earnings maximum and an additional 1.45\% tax for Medicare. These rates apply to both the employee and the employer such that while the employee pays $7.65 \%$ directly, the total FICA tax rate is $15.3 \%$. The taxable earnings maximum is increased annually based on the average national wage. In 2015 , the maximum was set at $\$ 118,500$. FICA taxes are typically directly withheld from employees' paychecks such that changes in the payroll tax are often immediately observable to taxpayers.

The Making Work Pay Tax Credit (MWPTC) was enacted by the American Recovery and Reinvestment Act of 2009 (ARRA), signed into law on February 17, 2009. The MWPTC provided $6.2 \%$ of earned income up to a maximum of $\$ 400$ for individuals or $\$ 800$ for married couples, inducing a kink at $\$ 6,451$ and $\$ 12,903$ of labor earnings, respectively. A 6.2 percentage point credit effectively eliminated the Social Security tax until the household reached the maximum of the MWPTC. A primary motivation behind the MWPTC was to increase consumer spending as part of the stimulus, but it also had the effect of reducing the tax rate for earned income at low levels of earnings. For most taxpayers, the Making Work 
Pay Tax Credit reduced the amount withheld from their paycheck until they reached the maximum credit. The MWPTC was not the first stimulus provided to households during the Great Recession. In 2008, the Economic Stimulus Act of 2008 had provided one-time payments to approximately $85 \%$ of tax units through economic stimulus payments, totaling about $\$ 96$ billion. Recent research found that the economic stimulus payments increase consumer spending on both durable and nondurable goods (Parker et al. (2013); Broda and Parker (2014)). Sahm, Shapiro and Slemrod (2012) finds that the MWPTCs induced about half the spending response that the 2008 stimulus payments did. In complementary work, Powell (2015) provides evidence that the 2008 stimulus payments resulted in short-term household labor supply reductions as the payments partially crowded out labor supply. The MWPTC, by lowering the tax rate, potentially had the opposite effect.

The MWPTC was phased out at a rate of $2 \%$ for incomes about $\$ 75,000(\$ 150,000$ for married couples). This phaseout was based on all taxable income, which I do not observe in the data. Consequently, I will not study the effects of the kink generated by the phaseout. Because of the interest in increasing consumer spending, the IRS altered the withholding tables to provide the credit to households throughout the year instead of issuing the credit when households filed their tax returns. The new withholding tables were issued in March and employers were required to adopt them by April 1, 2009. The MWPTC over its two years cost a total of $\$ 104.4$ billion. $^{2}$

The MWPTC ended in 2010 and was replaced by the Payroll Tax Holiday in 2011 and 2012. On December 17, 2010, President Barack Obama signed the Tax Relief, Unemployment Insurance Reauthorization, and Job Creation Act of 2010 which included over $\$ 800$ billion in tax reductions. The bill reduced the employee portion of the Social Security tax to 4.2 percentage points, a 2 percentage point decrease. This reduction affected labor earnings up

\footnotetext{
${ }^{2}$ http://www.recovery.gov/arra/Transparency/fundingoverview/Pages/taxbenefits-details.aspx
} 
to the taxable earnings maximum of $\$ 106,800$. Thus, each individual was eligible for payroll tax savings up to $\$ 2,136$, but this full benefit was only received by those earning at least the maximum. The payroll tax reduction was estimated to cost about $\$ 120$ billion annually. ${ }^{3}$ The tax cut was initially passed for 2011 only but was extended by two months by the The Temporary Payroll Tax Cut Continuation Act of 2011 and then for the rest of 2012 by the Middle Class Tax Relief and Job Creation Act of 2012. It was not extended past the end of 2012.

There are a couple reasons that we might expect to see additional responsiveness to the MWPTC in 2010 relative to 2009. First, households had the full 2010 tax year to respond to the credit. The credit was implemented partway through 2009, providing less opportunity to adjust behavior. For example, households with preferences to work until they reached the credit maximum may have already passed that point before the credit was even implemented. Second, Sahm, Shapiro and Slemrod (2012) report a lack of awareness about the credit in 2009, suggesting that households may not have learned about the credit until the following year. For these reasons, I will present some results which separate the responsiveness in 2009 from the responsiveness in 2010. Consistent with the hypothesis that we should observe additional responsiveness in 2010, I find larger estimates in the second year of the MWPTC.

\subsection{Theoretical Concepts}

This paper studies changes in nonlinear budgets, including the introduction of convexities to the budget constraint and a slope change around a non-convexity in the budget constraint. Figure 1 provides examples for both convex and non-convex kinks along with indifference

\footnotetext{
${ }^{3}$ https://www.whitehouse.gov/the-press-office/2010/12/07/fact-sheet-framework-agreement-middleclass-tax-cuts-and-unemployment-in
} 
curves representing household preferences. On the left, I show the theoretical effects of a convexity in the budget constraint. Under a linear tax, the household would optimize at point $A$. When the kink is introduced, the household reduces its labor supply to point $B$, close to the kink. Consequently, there are households that react to the kink by reducing their labor supply. In this paper, I study a kink caused by a tax rate reduction below the created kink. The conclusions about the relative earnings density remain the same, however. Households are more likely to locate around than the kink than they would in a tax regime without the kink.

In the right panel of Figure 1, I show a non-convex budget constraint. If the tax rate were linear at the same rate as below the kink, the household would locate at point $B$. The tax rate reduction above the kink, however, induces the household to (possibly) relocate to a higher level of pre-tax earnings at point $A$. In Figure 1, the household is indifferent between the two points but may still increase earnings. The reform studied in this paper at this part of the earnings distribution decreased the tax rate below the kink. This alters the degree of the non-convexity. The non-convexity encourages households to not locate close to the kink as those points are likely dominated by points above the kink. Thus, a non-convex kink should lead to "spreading," not bunching. However, when the budget constraint becomes less non-convex, more household should locate near the kink. Consequently, I expect to observe an increased density near the taxable earnings maximum in 2011. In a relative sense, this will look like bunching.

\section{Data}

Isolating "bunching" is difficult when earnings are reported with error. Even classical measurement error will lead to significant bias since we will not observe as much bunching as we 
should. Consequently, it is important to use administrative data. In this paper, I use the Continuous Work History Sample (CWHS) 1\% sample. This data set is longitudinal and contains information on labor earnings, Social Security benefits, year of birth, and several other administrative variables. I focus on a few key variables. First, I use "Medicare Taxable Earnings," which has the advantage that it is not topcoded. This property is important when I study behavior around the taxable maximum kink. I also use information about selfemployment earnings to select on people with self-employment earnings, given that previous research has found that individuals with self-employment income are the primary responders to taxes. The CWHS merges together data from several sources. The earnings data come from the Master Earnings File and comprises IRS tax data. Thus, the observed earnings for each person is the exact amount observed from the IRS, the administrative variable which determines the magnitude of the tax credits studied in this paper.

For my analysis, I select on individuals ages 25-55. The CWHS has only been updated to 2011 at this time so I use earnings from 2008 to 2011 in my analysis. I focus on this time period because it encompasses the policy changes that I am studying while including years in a similar economic environment to act as controls. To study bunching caused the MWPTC, I compare 2009 and 2010 earnings densities to the densities in the same parts of the earnings distribution in 2008 and 2011. For the payroll tax holiday, I compare the 2011 earnings distribution around the taxable earnings maximum to the same part of the distribution in 2009-2010. A further advantage of these years is that the taxable maximum was constant during this time period such that the primary change in payroll taxes was due to the 2011 payroll tax holiday. The Annual Social Security Wage Base Limit was $\$ 106,800$ between 2009 and 2011 .

Unfortunately, the CWHS does not contain marital status so it is not possible to know which MWPTC maximum that the individual would have responded to (nor do I know 
spousal earnings to construct total household labor earnings). This will attenuate the effect that I estimate. I created "bins" based on total individual annual earnings. These bins are $\$ 400$ in size and centered around each kink. For example, the first MWPTC kink is at $\$ 6,451$ so I create a bin which includes all individuals with earnings greater than $\$ 6,051$ and less than or equal to $\$ 6,451$. I do this for each kink such that bins marked as " $\$ 0$ " relative to the bin consist of people with earnings greater than $\$ 400$ less than kink up to earnings exactly at the kink.

\section{Empirical Strategy}

The bunching literature typically assumes that the earnings density, in the absence of kinks, is locally constant or smooth. This assumption is difficult to test. The main advantage of using payroll tax changes is that it permits the use of panel data to account for the underlying (fixed) earnings distribution, which may or may not be smooth around the kinks. Using the CWHS, I create bins or cells based on earnings relative to each kink and count the number of people in each bin. That is the outcome variable that I will model. I study the earnings distribution in each year relative to the kink. My primary specification is

$$
\begin{array}{r}
S_{c t}=\exp \left[\alpha_{c}+\gamma_{t}+\beta_{1}[\mathbf{1}(-\delta<\text { Earnings - Kink } \leq 0) \times \mathbf{1}(2008 \leq t \leq 2009)]\right. \\
\left.+\beta_{1}[\mathbf{1}(0<\text { Earnings }- \text { Kink } \leq \delta) \times \mathbf{1}(2008 \leq t \leq 2009)]+f_{t}(c)\right] \mu_{c t}
\end{array}
$$

where $S_{c t}$ is the number of people in cell (or bin) $c$ in year $t$. I estimate this specification separately for each MWPTC kink. Each sample includes all bins within $\$ 6,000$ of the kink. The specification includes bin fixed effects to account for the fixed underlying earnings distribution around the kink. The time fixed effects account for changes in the size of the total

number of people within $\$ 6,000$ of the kink. $f_{t}(c)$ is a function which varies by year, permit- 
ting the earnings distribution to change for reasons other than the tax rate changes. This function must be parametric and I use a quadratic functional form for most the analysis. The results are not sensitive to this choice.

I study the effects of each MWPTC kink on the earnings density within $\delta=\$ 800$ of the kink. Theory suggests that we should observe a higher fraction of individuals near the kink, suggesting that $\beta_{1}$ and/or $\beta_{2}$ should be positive. I allow the effect to differ based on whether the bin is below or above the kink. I disaggregate the effects for directly below and directly above the kink because individuals may have optimization error and not locate precisely at the kink. Disaggregating the effects allows for estimation of bunching even in the presence of optimization error while permitting some flexibility.

The tax holiday specification is similar. However, it allows a change in the earnings density around the kink in 2011, using 2009 and 2010 as controls. Equation (2) models the density as an exponential function. It is common in applied work to use a log-linear specification, but Silva and Tenreyro (2006) shows that an exponential functional form relaxes some restrictions imposed by a log-linear specification. They recommend estimation using Poisson regression. Recent work has shown that Poisson regression with two sets of fixed effects does not suffer from an incidental parameters problem (Fernández-Val and Weidner (2014)). I will also provide log-linear estimates. The conclusions do not substantially differ across the different estimation methods.

To derive elasticities similar to the method applied in Saez (2010), I estimate

$$
S_{c t}=\exp \left[\alpha_{c}+\gamma_{t}+\phi\left[\ln \left(\frac{1-\tau_{0}}{1-\tau_{1}}\right)_{t} \times \mathbf{1}(c \text { is close to kink })\right]+f_{t}(c)\right] \mu_{c t},
$$

$\frac{1-\tau_{0}}{1-\tau_{1}}$ is the ratio of the payroll net-of-tax rate at the kink. $\tau_{0}$ represents the rate below the kink and $\tau_{1}$ represents the rate above the kink. This variable is set equal to 0 for most bins. 
It is only non-zero for cells close to the kink. $\phi$ is not the elasticity of interest but must be appropriately scaled by the earnings level at the kink divided by the number of households at the kink (I use the average number in the "untreated" years for the number of households). I estimate specifications (2) and (3) for three groups: all taxpayers; taxpayers with no selfemployment income; and taxpayers with positive self-employment earnings.

An advantage of using policy changes to study bunching is that I can account for bunching that is not caused by the policy itself. This bunching may occur because of underlying factors determining the labor earnings distribution or due to other policies, such as the EITC. In fact, we can observe bunching due to the EITC in our data. Saez (2010) finds that taxpayers reporting self-employment income bunch at the minimum income necessary to receive the full credit. Table 1 lists this income level by year and number of children. It stays relatively constant over this time period such that bin fixed effects should account for bunching in the earnings density due to the EITC.

\section{$5 \quad$ Results}

\subsection{Graphical Evidence}

Figure 2 displays the earnings densities around the first MWPTC kink at $\$ 6,451$ of labor earnings. The dollar values on the x-axis represent the top value of the bin. The figures include the density in 2009/2010 and, for comparative purposes, 2008/2011. The left figure includes taxpayers with no reported self-employment earnings. We observe very little change in the densities due to the MWPTC. The right figure select on individuals which report a positive amount of self-employment income in the year. There are two striking features in this figure. First, the effect of the EITC on the earnings distribution is evident at the 
"one child" maximum credit level. This motivates the use of panel data with bin fixed effects to account for these fixed aspects of the earnings distribution during this time period. Cross-sectional analysis would struggle to model such discrete jumps not caused directly by the reform of interest. Second, there is evidence of increased bunching due to the MWPTC. Relative to the EITC, this bunching is small but that is to be expected due to the temporary nature of the MWPTC and the small size of the credit when compared to the EITC credit rate.

Figure 3 presents the corresponding densities around the second MWPTC kink at $\$ 12,903$ of labor earnings. This kink is relevant to married couples filing jointly. As before, there is little evidence that people without self-employment income are responsive to the tax credit. However, we observe a large shift in the density for individuals with positive selfemployment income. This kink is close to the kink created by the EITC (for those with $2+$ children), but the bunching becomes more pronounced in the years of the MWPTC. ${ }^{4}$

In Figure 4, I show the densities around the Social Security taxable earnings maximum. Given that the maximum creates a non-convexity in the budget constraint, we should observe "spreading" around this kink. However, the payroll tax holiday made the tax rate change at the maximum less pronounced such that we should observe less spreading. Consequently, we should expect to see the densities rise around the kink in 2011. I show the densities for 2009/2010 and then for 2011. Because there are fewer people with earnings close to the maximum, I create $\$ 1,200$ bins and show bins within $\$ 3,600$ of the kink. Even for individuals without self-employment income, there is evidence that the density changed when the payroll tax holiday was in effect. The density around the kink increased. For taxpayers with positive self-employment income, there is also some evidence of an earnings

\footnotetext{
${ }^{4}$ The EITC kink does change bins between 2008 and 2009 so this could explain why there is less of a pronounced spike for the 2008/2011 density. However, note that the 2009/2010 density is above the 2008/2011 density even in the bin below the MWPTC kink (where the EITC kink was in 2008), suggesting that this cannot explain the additional bunching in 2009/2010.
} 
density shift. There is an especially large jump in the $\$ 0-\$ 1,200$ bin above the kink. Caution is warranted, however, given that only 165 people in the data are in that bin for 2011. But the consistency of the higher densities around the kink in both of the figures is suggestive that the payroll tax holiday may have impacted behavior around the kink.

\subsection{Regression Estimates}

In Table 2, I present regression estimates of equations (2) and (3). I estimate these equations for all taxpayers within $\$ 6,000$ of the kink. I also estimate separately by self-employment status. The first parameter is the relative change in the density in the $\$ 800$ below the kink, and the second parameter refers to the change in the density for the $\$ 800$ above the kink. I include the results of a joint hypothesis test where the null hypothesis is that both of these parameters are equal to 0 . I also present the results of a hypothesis test for the null hypothesis that the sum of the two parameters is equal to 0 . In the last row, I present the elasticity estimated generated by estimation of equation (3).

There is little evidence of increased bunching at this kink for the full sample and for the sample without any self-employment earnings. However, the estimates do imply bunching for individuals with self-employment income, consistent with the graphical evidence in Figure 2. The parameter on the "Above Kink" variable implies that the MWPTC increased the number of people with income above the kink but less than $\$ 800$ from the kink by almost $7 \%$. The implied tax elasticity is 0.716 , though this is not statistically significant from 0 .

Because the MWPTC was implemented in the middle of 2009, we may expect different responsiveness in 2009 and 2010. Table 3 presents separate estimates by year. These estimates are jointly estimated, but the effect of the MWPTC is allowed to vary by year. Focusing on the self-employment group, there is some evidence that the estimates are larger in 
magnitude in 2009, though these differences are small. In general, the estimates are generally consistent across the two years.

Table 4 presents the estimates for the married couples kink generated by the MWPTC. Again, there is little evidence that people without self-employment earnings respond to payroll tax changes. However, I estimate a large response by individuals with selfemployment income. Both below and above the kink, the densities increase in the MWPTC years. The implied elasticity is 1.6. In Table 5, I disaggregate this effect by year. Consistent with the hypothesis that there should be a larger effect in 2010, I estimate more responsiveness to the MWPTC in 2010. The implied elasticity for 2009 is over 1.3, while the estimated elasticity for 2010 is over 1.8. Both estimates are statistically significant at the $5 \%$ level, but the confidence intervals are also rather large and I cannot rule out much smaller elasticities.

Behavior at the taxable earnings maximum is especially policy-relevant as it is indicative of how changes to the maximum or elimination of the maximum would impact labor supply. For these estimates, I only use the 2009-2011 data. ${ }^{5}$ Table 6 presents estimates about behavioral responses at this kink to changes in the payroll tax at earnings below the maximum. The estimates imply that individuals are very responsive at the taxable earnings maximum. While bunching around the non-convex kink is - in principle - not optimal, the payroll tax holiday reduced the degree of this non-convexity and induced bunching relative to baseline. The estimates imply that the payroll tax holiday increased the number of individuals with earnings below the maximum but within $\$ 800$ by over $6 \%$. The implied elasticity is 0.08. Unlike the MWPTC results, individuals with no self-employment income are driving this result. In fact, I do no estimate any statistically significant effect for individuals with self-employment income. This is partially due to the parameterization that I have used in

\footnotetext{
${ }^{5}$ Including 2008 has little effect on the estimates.
} 
terms of how I define "near" the kink. As discussed earlier, Figure 4 suggests an increase in the earnings density at a higher level of earnings. However, the number of individuals with self-employment income around the kink is relatively small so noise is also a contributing factor. This last result suggests that understanding the ramifications of raising or eliminating the payroll tax cap must consider the subsequent labor supply responses to this policy change.

\subsection{Robustness of Estimates}

In Table 7, I replicate previous results using a log-linear functional form, estimated by OLS. The results are very similar to the Poisson estimates. While Silva and Tenreyro (2006) argues that Poisson estimation imposes fewer assumptions than its log-linear counterpart, I find little evidence of bias here. The main conclusions of this paper remain the same even when OLS estimation is employed.

For the main estimates, I construct bins within $\$ 6,000$ of each kink. In principle, the estimates in this paper should be less sensitive to the range of earnings included in the analysis relative to those found using only cross-sectional earnings density estimation. The bin fixed effects non-parametrically account for the underlying earnings density. The specification even permits some parametric changes in the density in each year by including a quadratic term as a function of the bins. Table 8 studies whether the choice of the sample is driving the estimates more explicitly. I limit the sample to earnings within $\$ 4,400$ of the kink in Table 8 and replicate my previous estimates. The estimates are generally similar, suggesting that the bin fixed effects and the quadratic function $f_{t}(c)$ are adequate in terms of modeling the underling earnings distribution around the kinks. 


\section{Discussion and Conclusion}

Payroll tax reform represents a possible solution to extending the solvency of Medicare and Social Security. While we have many estimates of responsiveness to income taxes in the United States, there is less evidence concerning sensitivity to payroll taxes specifically. I find evidence that payroll tax changes do impact labor supply behavior. The MWPTC created bunching at kinks, primarily among those with self-employed income. This is potentially a function of reporting behavior and not true labor supply changes. The payroll tax holiday changed behavior at the taxable earnings maximum. I estimate an elasticity of about 0.08, primarily driven by people with no self-employment income. This elasticity is modest relative to the tax literature which has often found estimates in the range of 0.1 to 0.4 . Moreover, the elasticity of taxable income literature typically shows that high-income taxpayers are more responsive to income taxes relative to low-income taxpayers, suggesting additional caution in raising or eliminating the payroll tax cap. My estimates imply a more modest response.

However, it is the first documented behavioral responses to the Social Security earnings maximum and implies that using the maximum as a policy lever must account for labor supply behavioral responses.

This paper uses multiple payroll tax policy changes to study responsiveness to payroll taxes. By studying only behavior around the kinks, my estimates are only pertinent to those parts of the distribution. If individuals at very high earnings (well above the maximum) do not respond at all to payroll taxes, this method will not uncover that inelasticity. Furthermore, the policy changes studied in this paper were short-term and individuals may not have had time to respond optimally to the policies or fixed costs may have made such responses sub-optimal in the short-run. I present some evidence that long-term behavior may be different as responsiveness to the MWPTC increased in its second year, possible 
evidence of the importance of learning. However, given the rarity of payroll tax changes in the United States, these estimates present some of the first natural experiment evidence of responsiveness to payroll taxes. 


\section{References}

Auten, Gerald, and Robert Carroll. 1999. "The Effect Of Income Taxes On Household Income." The Review of Economics and Statistics, 81(4): 681-693.

Bastani, Spencer, and Håkan Selin. 2014. "Bunching and non-bunching at kink points of the Swedish tax schedule." Journal of Public Economics, 109: 36-49.

Broda, Christian, and Jonathan A Parker. 2014. "The economic stimulus payments of 2008 and the aggregate demand for consumption." Journal of Monetary Economics, 68: S20-S36.

Brown, Kristine M. 2013. "The link between pensions and retirement timing: Lessons from California teachers." Journal of Public Economics, 98: 1-14.

Burtless, Gary, and Jerry A Hausman. 1978. "The effect of taxation on labor supply: Evaluating the Gary negative income tax experiment." The Journal of Political Economy, 1103-1130.

Chetty, Raj, John N. Friedman, Tore Olsen, and Luigi Pistaferri. 2011. "Adjustment Costs, Firm Responses, and Micro vs. Macro Labor Supply Elasticities: Evidence from Danish Tax Records." The Quarterly Journal of Economics, 126(2): 749-804.

Fernández-Val, Iván, and Martin Weidner. 2014. "Individual and time effects in nonlinear panel models with large N, T."

Friedberg, Leora. 2000. "The Labor Supply Effects of the Social Security Earnings Test." The Review of Economics and Statistics, 82(1): 48-63.

Gelber, Alexander M, Damon Jones, and Daniel W Sacks. 2013. "Earnings Adjustment Frictions: Evidence from the Social Security Earnings Test." National Bureau of Economic Research.

Gruber, Jon, and Emmanuel Saez. 2002. "The elasticity of taxable income: evidence and implications." Journal of Public Economics, 84(1): 1-32.

Gruber, Jonathan. 1997. "The Incidence of Payroll Taxation: Evidence from Chile." Journal of Labor Economics, 15(S3): S72-S101.

Haider, Steven J., and David S. Loughran. 2008. "The Effect of the Social Security Earnings Test on Male Labor Supply: New Evidence from Survey and Administrative Data." Journal of Human Resources, 43(1).

Hausman, JA. 1981. "Labor supply, in How Taxes Affect Economic Behavior(H. Aaron and J. Pechman, Eds.)." Brookings Institution, Washington, DC.

Hausman, Jerry A. 1985. "The econometrics of nonlinear budget sets." Econometrica: Journal of the Econometric Society, 1255-1282. 
Joint Committee on Taxation. 2015. "Overview of the Federal Tax System as in Effect for 2015."

Kugler, Adriana, and Maurice Kugler. 2009. "Labor Market Effects of Payroll Taxes in Developing Countries: Evidence from Colombia." Economic Development and Cultural Change, 57(2): 335-358.

Lehmann, Etienne, François Marical, and Laurence Rioux. 2013. "Labor income responds differently to income-tax and payroll-tax reforms." Journal of Public Economics, 99: $66-84$.

Liebman, Jeffrey, and Emmanuel Saez. 2006. "Earning Responses to Increases in Payroll Taxes." National Bureau of Economic Research.

OECD. 2015. "Taxing Wages 2015."

Parker, Jonathan A, Nicholas S Souleles, David S Johnson, and Robert McClelland. 2013. "Consumer Spending and the Economic Stimulus Payments of 2008." The American Economic Review, 103(6): 2530-2553.

Powell, David. 2015. "Does Labor Supply Respond to Transitory Income? Evidence from the Economic Stimulus Payments of 2008." RAND Labor \&\& Population Working Paper $W R, 710(3)$.

Saez, Emmanuel. 2010. "Do taxpayers bunch at kink points?" American Economic Journal: Economic Policy, 180-212.

Saez, Emmanuel, Joel Slemrod, and Seth Giertz. 2012. "The elasticity of taxable income with respect to marginal tax rates: a critical review." Journal of Economic Literature, 50(1): 3-50.

Saez, Emmanuel, Manos Matsaganis, and Panos Tsakloglou. 2012. "Earnings determination and taxes: evidence from a cohort-based payroll tax reform in Greece." The Quarterly Journal of Economics, qjr052.

Sahm, Claudia R, Matthew D Shapiro, and Joel Slemrod. 2012. "Check in the Mail or More in the Paycheck: Does the Effectiveness of Fiscal Stimulus Depend on How It Is Delivered?" American Economic Journal: Economic Policy, 4(3): 216.

Silva, JMC Santos, and Silvana Tenreyro. 2006. "The log of gravity." The Review of Economics and Statistics, 88(4): 641-658.

Social Security Board of Trustees. 2015. "The 2015 Annual Report of the Board of Trustees of the Federal Old-Age and Survivors Insurance and Federal Disability Insurance Trust Funds." 


\section{Figures}

Figure 1: Nonlinear Budget Sets

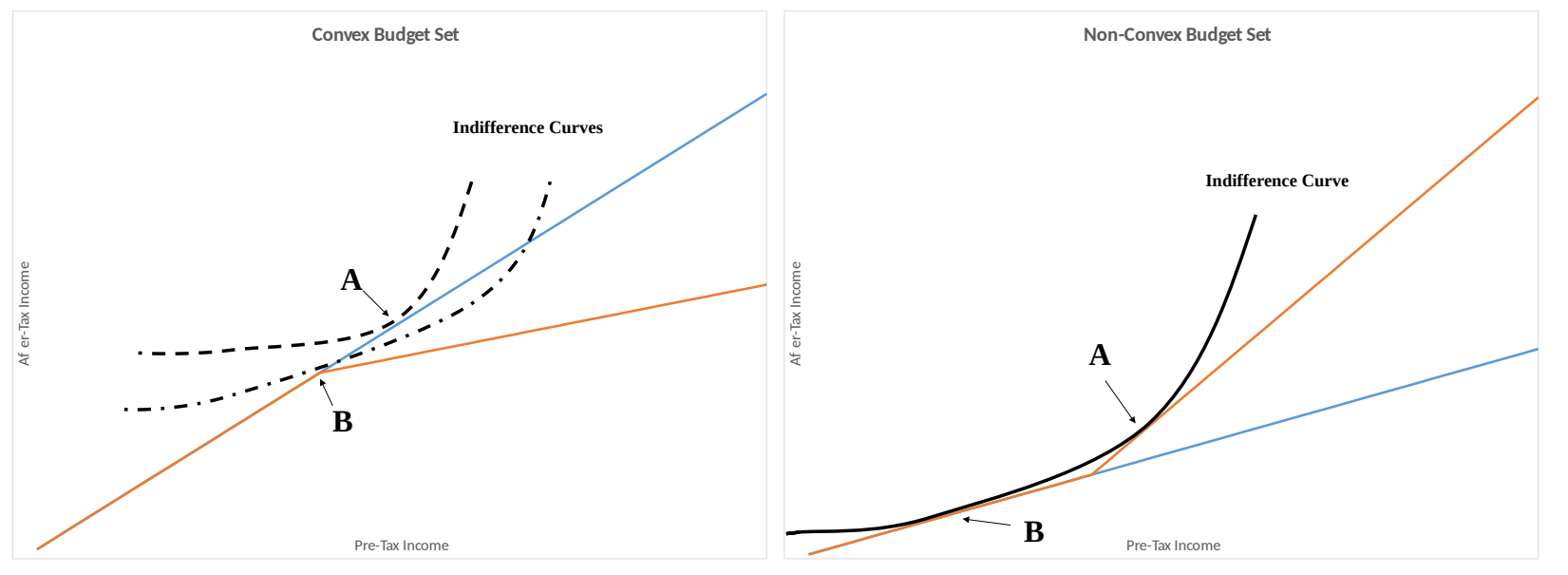


Figure 2: Earnings Densities Around \$6,451 of Labor Earnings

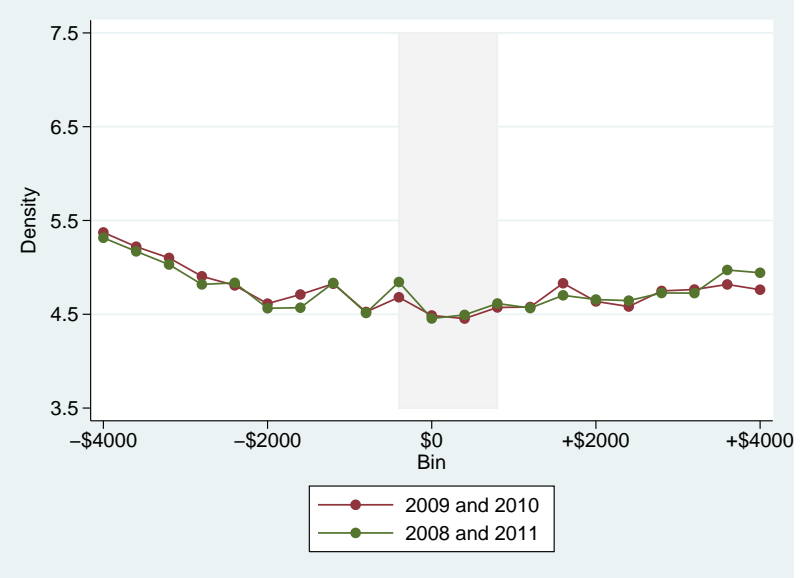

No Self-Employment Income

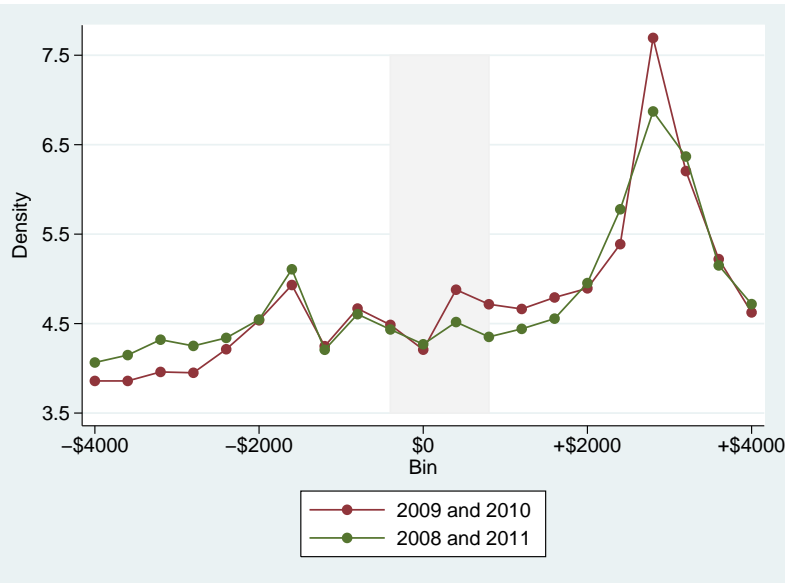

Positive Self-Employment Income

Source: Continuous Work History Sample

Notes: The Making Work Pay Tax Credit was active in 2008 and 2009. Each point represents a bin that is $\$ 400$ in size. The $y$-axis is the percentage of people within $\$ 4,000$ of the kink within each bin.

Figure 3: Earnings Densities Around $\$ 12,903$ of Labor Earnings

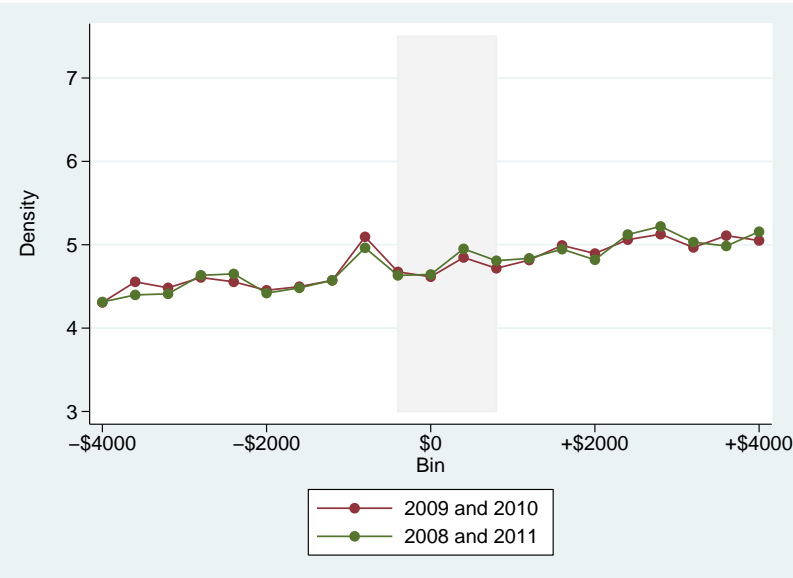

No Self-Employment Income

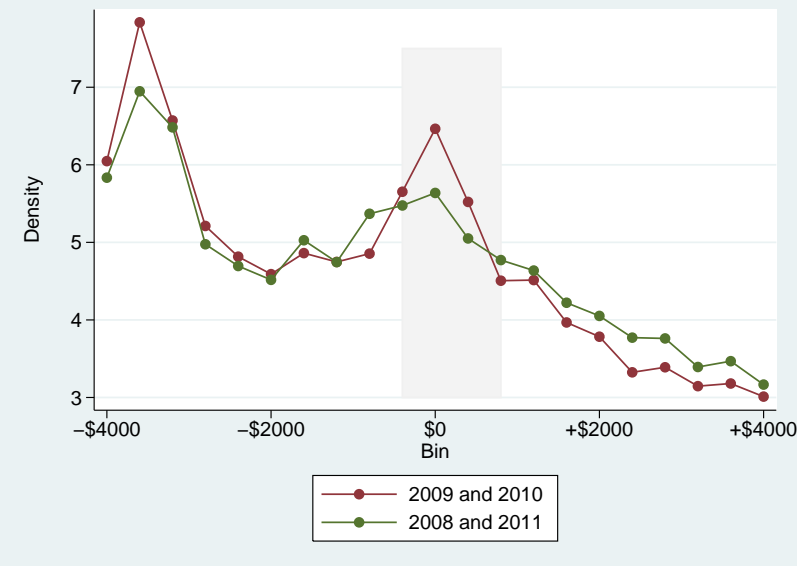

Positive Self-Employment Income

Source: Continuous Work History Sample

Notes: The Making Work Pay Tax Credit was active in 2008 and 2009. Each point represents a bin that is $\$ 400$ in size. The $y$-axis is the percentage of people within $\$ 4,000$ of the kink within each bin. 
Figure 4: Earnings Densities Around $\$ 106,800$ of Labor Earnings

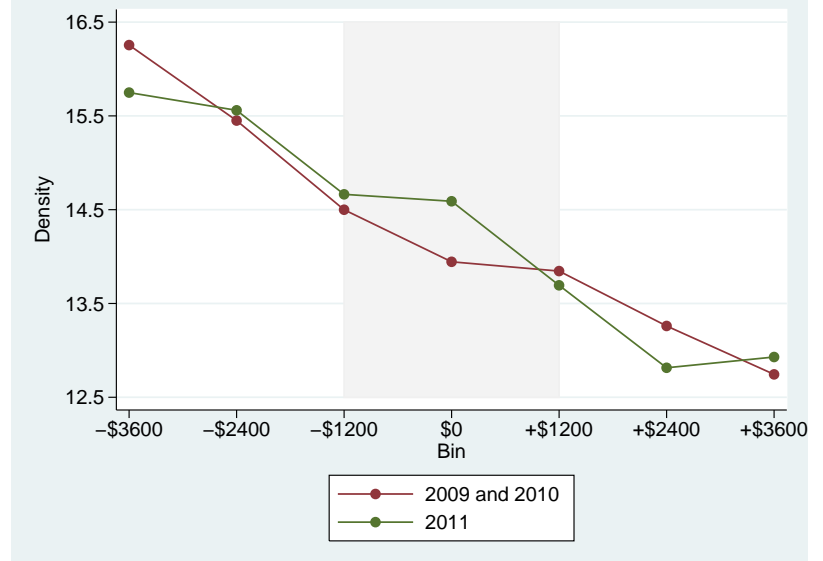

No Self-Employment Income

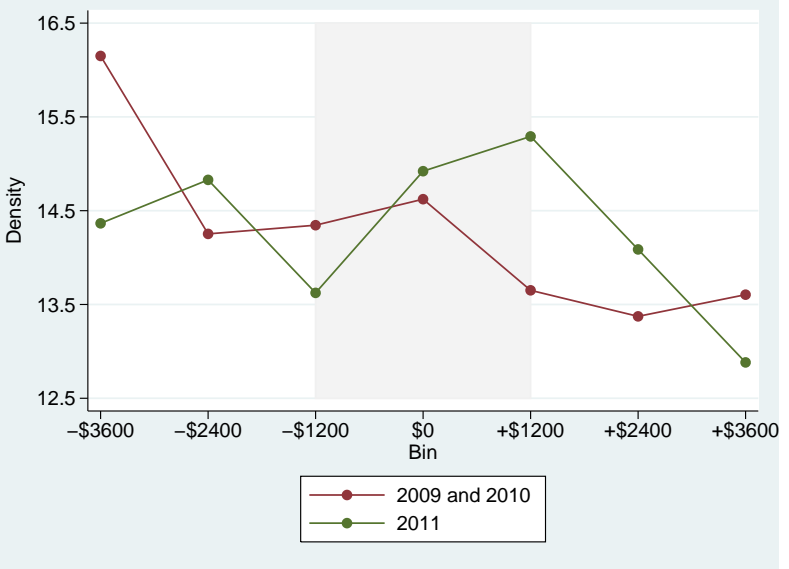

Positive Self-Employment Income

Source: Continuous Work History Sample

Notes: The Payroll Tax Holiday was active in 2011. Each point represents a bin that is $\$ 1,200$ in size. The $\mathrm{y}$-axis is the percentage of people within $\$ 3,600$ of the kink within each bin. 


\section{Tables}

Table 1: EITC Minimum Income for Maximum Credit by Tax Year

\begin{tabular}{ccccc}
\hline Year: & 2008 & 2009 & 2010 & 2011 \\
\hline No children & $\$ 5,720$ & $\$ 5,970$ & $\$ 5,980$ & $\$ 6,070$ \\
One child & $\$ 8,580$ & $\$ 8,950$ & $\$ 8,970$ & $\$ 9,100$ \\
Two children & $\$ 12,060$ & $\$ 12,570$ & $\$ 12,590$ & $\$ 12,780$ \\
Three children & $\$ 12,060$ & $\$ 12,570$ & $\$ 12,590$ & $\$ 12,780$
\end{tabular}

The credit rate is $7.65 \%$ for households with no children; $34 \%$ for household with one child; $40 \%$ for household with two children. Beginning in 2009 , the the credit rate was $45 \%$ for household with three or more children. 
Table 2: Poisson Estimates for First MWPTC Kink

Outcome Variable: Number of Taxpayers in Bin

All Not Self-Employed Self-Employed

$\begin{array}{cccc}\text { Under Kink } & -0.016 & -0.018 & -0.012 \\ & (0.013) & (0.015) & (0.027) \\ \text { Above Kink } & 0.009 & -0.011 & 0.067^{* *} \\ & (0.008) & (0.007) & (0.027) \\ \text { Joint Significance } & 0.072 & 0.171 & 0.000 \\ \text { Significance of Sum } & 0.711 & 0.089 & 0.289 \\ \text { Implied Elasticity } & -0.371 & -1.247^{*} & 0.716 \\ & (1.078) & (0.741) & (0.694)\end{array}$

Significance Levels: $* 10 \%,{ }^{*} 5 \%, * * * 1 \%$. Each observation is a $\$ 400$ bin in a year. Heteroscedastic-robust standard errors are reported in parentheses. Regressions also include bin fixed effects, time fixed effects, and a quadratic term for each year as a function of each bin relative to the kink. "Under Kink" refers to bins with earnings below the kink but within $\$ 800$ in 2009 and 2010. "Above Kink" refers to bins with earnings above the kink but within $\$ 800$ in 2009 and 2010 . "Joint Significance" refers to a joint hypothesis test that both reported coefficients in the column are equal to 0. "Significance of Sum" refers to a significance test that the sum of the parameters in each column sum to 0 . The implied elasticity is the estimate from estimation of specification (3). 
Table 3: Poisson Estimates for First MWPTC Kink by Year

\begin{tabular}{cccc}
\hline & All & Not Self-Employed & Self-Employed \\
\hline Under Kink (2009) & -0.017 & -0.017 & -0.018 \\
& $(0.011)$ & $(0.012)$ & $(0.027)$ \\
Above Kink (2009) & 0.011 & -0.008 & $0.065^{* *}$ \\
& $(0.009)$ & $(0.007)$ & $(0.028)$ \\
Under Kink (2010) & -0.016 & -0.019 & -0.007 \\
& $(0.018)$ & $(0.023)$ & $(0.029)$ \\
Above Kink (2010) & 0.008 & $-0.013^{*}$ & $0.069^{* *}$ \\
& $(0.009)$ & $(0.008)$ & $(0.029)$ \\
\hline 2009 & & & \\
Joint Significance & 0.029 & 0.247 & 0.000 \\
Significance of Sum & 0.756 & 0.095 & 0.375 \\
Implied Elasticity & -0.309 & -1.109 & 0.624 \\
& $(1.119)$ & $(0.674)$ & $(0.741)$ \\
\hline 2010 & & & 0.000 \\
Joint Significance & 0.290 & 0.197 & 0.262 \\
Significance of Sum & 0.729 & 0.197 & 0.810 \\
Implied Elasticity & -0.434 & -1.386 & $(0.751)$ \\
\hline
\end{tabular}

Significance Levels: $* 10 \%, * * 5 \%, * * * 1 \%$. Each observation is a $\$ 400$ bin in a year. Heteroscedastic-robust standard errors are reported in parentheses. Regressions also include bin fixed effects, time fixed effects, and a quadratic term for each year as a function of each bin relative to the kink. "Under Kink" refers to bins with earnings below the kink but within $\$ 800$. "Above Kink" refers to bins with earnings above the kink but within $\$ 800$. "Joint Significance" refers to a joint hypothesis test that both reported coefficients in the column are equal to 0. "Significance of Sum" refers to a significance test that the sum of the parameters in each column sum to 0 . The implied elasticity is the estimate from estimation of specification (3). 
Table 4: Poisson Estimates for Second MWPTC Kink Outcome Variable: Number of Taxpayers in Bin All Not Self-Employed Self-Employed

$\begin{array}{cccc}\text { Under Kink } & 0.031^{*} & -0.002 & 0.132^{* *} \\ & (0.016) & (0.009) & (0.064) \\ \text { Above Kink } & -0.001 & -0.021 & 0.075^{* *} \\ & (0.016) & (0.013) & (0.036) \\ \text { Joint Significance } & 0.141 & 0.261 & 0.030 \\ \text { Significance of Sum } & 0.182 & 0.164 & 0.010 \\ \text { Implied Elasticity } & 0.945 & -0.565 & 1.582^{* *} \\ & (0.746) & (0.417) & (0.629)\end{array}$

Significance Levels: $* 10 \%,{ }^{*} * 5 \%, * * * 1 \%$. Each observation is a $\$ 400$ bin in a year. Heteroscedastic-robust standard errors are reported in parentheses. Regressions also include bin fixed effects, time fixed effects, and a quadratic term for each year as a function of each bin relative to the kink. "Under Kink" refers to bins with earnings below the kink but within $\$ 800$ in 2009 and 2010. "Above Kink" refers to bins with earnings above the kink but within $\$ 800$ in 2009 and 2010 . "Joint Significance" refers to a joint hypothesis test that both reported coefficients in the column are equal to 0. "Significance of Sum" refers to a significance test that the sum of the parameters in each column sum to 0 . The implied elasticity is the estimate from estimation of specification (3). 
Table 5: Poisson Estimates for Second MWPTC Kink by Year

\begin{tabular}{cccc}
\hline & All & Not Self-Employed & Self-Employed \\
\hline Under Kink (2009) & $0.025^{*}$ & 0.001 & $0.108^{*}$ \\
& $(0.015)$ & $(0.012)$ & $(0.063)$ \\
Above Kink (2009) & $-0.018^{*}$ & $-0.040^{* *}$ & $0.063^{*}$ \\
& $(0.010)$ & $(0.014)$ & $(0.037)$ \\
Under Kink (2010) & $0.036^{*}$ & -0.005 & $0.154^{* *}$ \\
& $(0.019)$ & $(0.009)$ & $(0.068)$ \\
Above Kink (2010) & 0.017 & -0.003 & $0.087^{* *}$ \\
& $(0.018)$ & $(0.013)$ & $(0.043)$ \\
\hline 2009 & & & 0.093 \\
Joint Significance & 0.019 & 0.017 & 0.032 \\
Significance of Sum & 0.730 & 0.052 & $1.308^{* *}$ \\
Implied Elasticity & 0.226 & -0.944 & $(0.622)$ \\
& $(0.787)$ & $(0.612)$ & 0.020 \\
\hline 2010 & & & 0.006 \\
Joint Significance & 0.130 & 0.858 & $1.845^{* * *}$ \\
Significance of Sum & 0.057 & 0.666 & $(0.685)$ \\
Implied Elasticity & $1.664^{*}$ & -0.180 & \\
& $(0.890)$ & $(0.455)$ & \\
\hline
\end{tabular}

Significance Levels: $* 10 \%, * * 5 \%, * * * 1 \%$. Each observation is a $\$ 400$ bin in a year. Heteroscedastic-robust standard errors are reported in parentheses. Regressions also include bin fixed effects, time fixed effects, and a quadratic term for each year as a function of each bin relative to the kink. "Under Kink" refers to bins with earnings below the kink but within $\$ 800$. "Above Kink" refers to bins with earnings above the kink but within $\$ 800$. "Joint Significance" refers to a joint hypothesis test that both reported coefficients in the column are equal to 0. "Significance of Sum" refers to a significance test that the sum of the parameters in each column sum to 0 . The implied elasticity is the estimate from estimation of specification (3). 
Table 6: Poisson Estimates for Taxable Earnings Maximum Kink Outcome Variable: Number of Taxpayers in Bin

$\begin{array}{cccc} & \text { All } & \text { Not Self-Employed } & \text { Self-Employed } \\ \text { Under Kink } & 0.061^{* * *} & 0.072^{* * *} & -0.065 \\ & (0.019) & (0.018) & (0.110) \\ \text { Above Kink } & 0.021 & 0.026 & -0.040 \\ & (0.036) & (0.034) & (0.108) \\ \text { Joint Significance } & 0.006 & 0.000 & 0.812 \\ \text { Significance of Sum } & 0.062 & 0.019 & 0.534 \\ \text { Implied Elasticity } & 0.083^{*} & 0.091^{* *} & -0.009 \\ & (0.046) & (0.041) & (0.014)\end{array}$

Significance Levels: ${ }^{*} 10 \%,{ }^{*} * 5 \%, * * * 1 \%$. Each observation is a $\$ 400$ bin in a year. Heteroscedastic-robust standard errors are reported in parentheses. Regressions also include bin fixed effects, time fixed effects, and a quadratic term for each year as a function of each bin relative to the kink. "Under Kink" refers to bins with earnings below the kink but within $\$ 800$ in 2011. "Above Kink" refers to bins with earnings above the kink but within $\$ 800$ in 2011. "Joint Significance" refers to a joint hypothesis test that both reported coefficients in the column are equal to 0. "Significance of Sum" refers to a significance test that the sum of the parameters in each column sum to 0 . The implied elasticity is the estimate from estimation of specification (3). 
Table 7: Log-linear Estimation

\section{First MWPTC Kink}

All Not Self-Employed Self-Employed

$\begin{array}{cccc}\text { Under Kink } & -0.017 & -0.018 & -0.011 \\ & (0.016) & (0.018) & (0.027) \\ \text { Above Kink } & 0.009 & -0.011 & 0.068^{* *} \\ & (0.010) & (0.008) & (0.026) \\ \text { Joint Significance } & 0.195 & 0.281 & 0.000 \\ \text { Significance of Sum } & 0.709 & 0.158 & 0.277\end{array}$

Second MWPTC Kink

All Not Self-Employed Self-Employed

$\begin{array}{cccc}\text { Under Kink } & 0.031 & -0.002 & 0.134^{*} \\ & (0.019) & (0.011) & (0.080) \\ \text { Above Kink } & -0.001 & -0.021 & 0.071^{*} \\ & (0.017) & (0.016) & (0.042) \\ \text { Joint Significance } & 0.271 & 0.413 & 0.095 \\ \text { Significance of Sum } & 0.285 & 0.263 & 0.036\end{array}$

Taxable Earnings Maximum Kink

All Not Self-Employed Self-Employed

\begin{tabular}{cccc} 
Under Kink & $0.057^{* * *}$ & $0.076^{* * *}$ & -0.103 \\
& $(0.019)$ & $(0.024)$ & $(0.180)$ \\
Above Kink & 0.014 & 0.023 & -0.064 \\
& $(0.037)$ & $(0.035)$ & $(0.119)$ \\
Joint Significance & 0.016 & 0.010 & 0.767 \\
Significance of Sum & 0.122 & 0.037 & 0.472 \\
\hline
\end{tabular}

Significance Levels: ${ }^{*} 10 \%,{ }^{*} * 5 \%,{ }^{* * *} 1 \%$. All estimates generated by OLS estimation of log-linear specification. Each observation is a $\$ 400$ bin in a year. Heteroscedastic-robust standard errors are reported in parentheses. Regressions also include bin fixed effects, time fixed effects, and a quadratic term for each year as a function of each bin relative to the kink. "Under Kink" refers to bins with earnings below the kink but within $\$ 800$ in the respective treated years. "Above Kink" refers to bins with earnings above the kink but within $\$ 800$ in the respective treated years. "Joint Significance" refers to a joint hypothesis test that both reported coefficients in the column are equal to 0 . "Significance of Sum" refers to a significance test that the sum of the parameters in each column sum to 0 . 
Table 8: Poisson Estimates using Sample within $\$ 4,400$ of Kink

\begin{tabular}{|c|c|c|c|}
\hline \multicolumn{4}{|c|}{ First MWTPC Kink } \\
\hline \multirow{3}{*}{ Under Kink } & All & Not Self-Employed & Self-Employed \\
\hline & 0.006 & -0.022 & -0.007 \\
\hline & $(0.009)$ & $(0.015)$ & $(0.024)$ \\
\hline \multirow[t]{2}{*}{ Above Kink } & -0.019 & -0.013 & $0.067 * * *$ \\
\hline & $(0.013)$ & $(0.007)$ & $(0.024)$ \\
\hline Joint Significance & 0.089 & 0.102 & 0.000 \\
\hline Significance of Sum & 0.459 & 0.050 & 0.198 \\
\hline \multirow[t]{2}{*}{ Implied Elasticity } & -0.758 & $-1.524^{*}$ & 0.790 \\
\hline & $(1.093)$ & $(0.783)$ & $(0.633)$ \\
\hline \multicolumn{4}{|c|}{ Second MWTPC Kink } \\
\hline \multirow{3}{*}{ Under Kink } & All & Not Self-Employed & Self-Employed \\
\hline & $0.033^{* *}$ & -0.003 & $0.138^{* *}$ \\
\hline & $(0.016)$ & $(0.009)$ & $(0.068)$ \\
\hline \multirow[t]{2}{*}{ Above Kink } & 0.001 & $-0.023^{*}$ & $0.085^{*}$ \\
\hline & $(0.016)$ & $(0.013)$ & $(0.046)$ \\
\hline Joint Significance & 0.135 & 0.229 & 0.052 \\
\hline Significance of Sum & 0.177 & 0.153 & 0.015 \\
\hline \multirow[t]{2}{*}{ Implied Elasticity } & 1.068 & -0.628 & $1.694^{* *}$ \\
\hline & $(0.828)$ & $(0.450)$ & $(0.705)$ \\
\hline \multicolumn{4}{|c|}{ Taxable Earnings Maximum Kink } \\
\hline \multirow{3}{*}{ Under Kink } & All & Not Self-Employed & Self-Employed \\
\hline & $0.057 * * *$ & $0.071^{* * *}$ & -0.104 \\
\hline & $(0.019)$ & $(0.019)$ & $(0.114)$ \\
\hline \multirow{2}{*}{ Above Kink } & 0.018 & 0.027 & -0.081 \\
\hline & $(0.037)$ & $(0.035)$ & $(0.113)$ \\
\hline Joint Significance & 0.013 & 0.001 & 0.580 \\
\hline Significance of Sum & 0.091 & 0.026 & 0.302 \\
\hline \multirow[t]{2}{*}{ Implied Elasticity } & 0.076 & $0.091^{* *}$ & -0.016 \\
\hline & $(0.047)$ & $(0.043)$ & $(0.015)$ \\
\hline
\end{tabular}

Significance Levels: ${ }^{*} 10 \%,{ }^{*} * 5 \%,{ }^{* * *} 1 \%$. Each observation is a $\$ 400$ bin in a year. Heteroscedastic-robust standard errors are reported in parentheses. Regressions also include bin fixed effects, time fixed effects, and a quadratic term for each year as a function of each bin relative to the kink. "Under Kink" refers to bins with earnings below the kink but within $\$ 800$ in the respective treated years. "Above Kink" refers to bins with earnings above the kink but within $\$ 800$ in the respective treated years. "Joint Significance" refers to a joint hypothesis test that both reported coefficients in the column are equal to 0 . "Significance of Sum" refers to a significance test that the sum of the parameters in each column sum to 0 . 